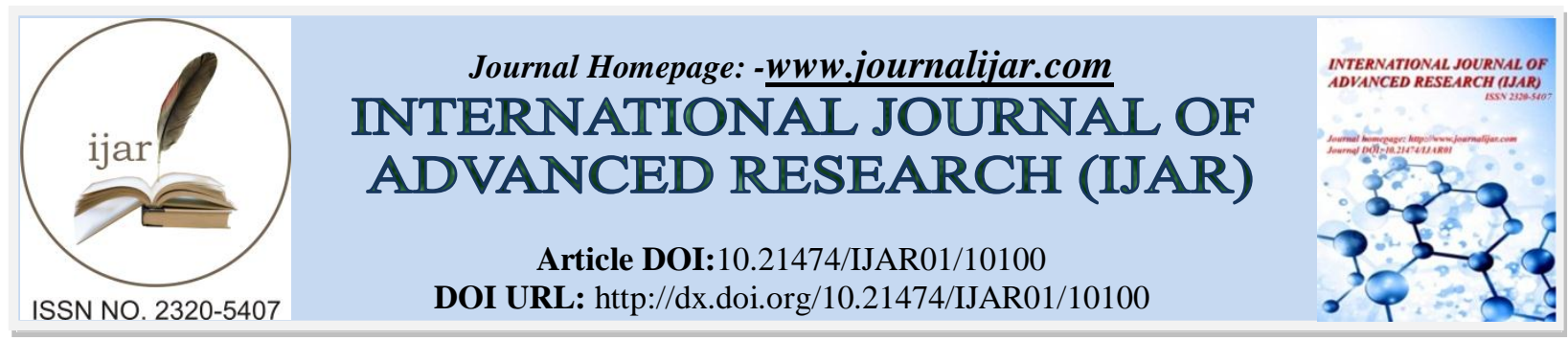

RESEARCH ARTICLE

\title{
COPYRIGHT PROTECTION FOR BUTON SPECIAL WEAVING MOTIF.
}

Rahman Hasima, Guasman Tatawu and Nur Intan.

Lecturer at Faculty of Law, Halu Oleo University Kendari, Indonesia.

\section{Manuscript Info}

\section{Manuscript History}

Received: 14 September 2019

Final Accepted: 16 October 2019

Published: November 2019

Key words:-

Copyright, Buton Weaving Motif, Protection.

\begin{abstract}
Copyright protection on Buton woven motifs is regulated in Law No. 28 of 2014 concerning Copyright in Article 38 paragraph (1), where the buton woven motifs can be said to be works of art in two dimensions made of textiles or their combination and Article 40 paragraph (1) letter $\mathrm{j}$ states that batik art and other motifs are protected creations. Furthermore, in the elucidation of Article 40 paragraph (1) letter $\mathrm{j}$, what is meant by other motifs, namely motifs which are the wealth of the Indonesian people found in various regions, such as buton and other motifs that are contemporary, innovative and continue to be developed and Factors weak copyright protection for weaving motifs Buton is : a) Factors legal subtance: the provisions of Law No. 28 of 2014 About Copyrights have not been applied effectively for weaving motifs Buton has not done recording and registered as a copyrighted work because they do not know the mechanism of copyright registration, do not know the types of violations of a work and buton weavers lack understanding about the economic rights or moral rights they get from the resulting work. b) Factors of legal structure: lack of human resources who have competence in the field of intellectual property rights, especially copyright and lack of socialization or counseling about the mechanism of registration of intellectual property rights, especially copyright. c) legal culture: the public or weavers still do not understand the mechanisms of copyright registration rights that must be met. In addition, the relatively high cost of obtaining copyrights is why people are reluctant to register for copyright.
\end{abstract}

Copy Right, IJAR, 2019,. All rights reserved.

\section{Introduction:-}

At the time of independence, the Indonesian State was determined to create a fair society, prosperous, prosperous in spiritual and material as it was we hoped. In line with Indonesia's commitment to participate in realizing world order as stated in the opening of the Constitution of the Republic of Indonesia 1945, Indonesia has a national need to harmonize and provide a suitable place for the regulation of its various intellectual property rights in accordance with universal rules.

IPR has become a very important issue and has received attention in both national and international forums. The inclusion of Trade Related Aspectsof Intellectual Property Rights, Including Trade in Counterfeit Goods (TRIPs) in the 1994 World Trade Organization (WTO) agreement package marks the start of a new era of IPR development

Corresponding Author: Rahman Hasima

Address: Lecturer at Faculty of Law, Halu Oleo University Kendari, Indonesia. 
throughout the world so that IPR issues cannot be separated from the world of trade and investment. The importance of IPR in economic development and trade has spurred the start of a new era of economic development based on science. ${ }^{1}$

The country of Indonesia is a country that rich in ethnicity and culture. Indonesia has more than 100 cultures in each region, the term culture not only refers to literature and art, but also to the overall way of life practiced by humans in everyday life which is transmitted from one generation to the next. ${ }^{2}$ Each region has different works of art, including traditional clothing, traditional dances and songs that have their own characteristics from each region. The artwork is used for traditional activities, but in its development the artwork has been used by the community in daily life.

In making these works of art, they are no longer based on existing standards, but are increasingly developing following the times. For example in the local traditional clothes that have been modified to make it look more modern, but still pay attention to the aesthetics of traditional culture. In the past, the use of some local traditional clothing was only intended for kings and aristocrats, but now there are many people who use it.

Nowadays, the artwork has become an economic support for the region. The development of the economy is growing faster along with the emergence of various new economic potentials. Starting with traditional works of art are now born a variety of ideas or new ideas that are more creative and innovative or also called creative industries. Creative industries are very influential on the development and growth of the Indonesian economy. One example of the creative industry is the textile industry.

The development of the textile industry in Indonesia can be said to be very fast and rapid. Currently there are many new fashion and fashion styles in Indonesia. This development is due to several things, one of which is the progress of Indonesian thinking about the importance of primary human needs, namely "clothing". Progress of such people's thoughts, the development of the textile industry is increasing. Various factories began to be established, opened up jobs, and began producing goods. But behind all the progress of the textile industry in producing a variety of the latest clothing models, there are several textile industries that produce traditional artworks, for example woven cloth typical of Buton.

Weaving typical Buton better known by the title "Sarung Buton". Holsters Buton in Wolio language, they called Bhia Wolio means sheath or fabric as the identity of the people of Buton wherever their located. Sheath Buton is one of the weaving typical native Indonesia were loaded by the life of the social culture of the people of Buton. Results of fabric weaving Buton is the result of a culture that is loaded of meanings as there in variety of dressing contained a guideline or conceptions, ideas that reflect connection between the human with the environment of nature. This is indicated by the presence of several kinds of colors or motifs found on the Buton weaving fabric whichis closely related to the surrounding nature. Sheath Buton plays an important role in the sociocultural life in his community .

Along with the times, sheath Buton has been shifted, its role not only be used as a complete outfit in the event of indigenous but it had become part of the fashion trend of society in some areas in the Southeast Sulawesi. Now the Buton weaving fabric which was once shaped as a sheath has been produced into a variety of clothing for both men and women.

Various modifications of clothing that patterned fabric weaving Buton now much loved by the community. All agencies of government and schools in the area of islands of Buton require the entire employee and his students to use a uniform that has patterned fabric weaving Buton on the day specified. The development of various motifs weaving Buton, causing some producers of clothes trying to modify motifs that already exist such, expanding it to other motifs, as well as changing the shape of the original fabric weaving Buton such that some parts of the motif is the missing. It it will create authentic value of motif Buton it will be reduced or changing .

One interesting issue that is currently developing within the scope of IPR studies is the legal protection of intellectual property produced by indigenous people or traditional communities, one of which is the Buton typical weaving handicraft.

Buton weaving craft has a variety of motifs that reflect the local wisdom of the local community so that it has great potential resources for development in the area of regional culture. However, the results of the Buton weaving craft have no legal protection efforts so that this can be used by other parties illegally by commercializing the theme or

\footnotetext{
${ }^{1}$ Director General of IPR and EC-ASEAN, Cooperation on Intellectual Property Rights (ECAP II), 2006, p. 8.

${ }^{2}$ I Gede Pitana, Introduction to Tourism Science, ANDI, Yogyakarta, p. 75.
} 
motif of the typical buton weaving which is carried out without permission. This has also happened in some areas that make use of local handicrafts without permission by parties who are not responsible, those people want to get economic benefit for it.

Buton weaving motifs are assets that need to be protected because the creator of the buton weaving motif has the rights to that work called copyright. Copyright is regulated in Law Number 28 of 2014 concerning Copyright, hereinafter referred to as the Copyright Act.

Article 1 number 1 of the Copyright Law states that copyright is the exclusive right of the creator which arises automatically based on the declarative principle after a Work is realized in tangible form without reducing restrictions in accordance with statutory provisions. Then in Article 1 number 3 of the Copyright Law states that a Work is every work of copyright in the fields of science, art, and literature that results from inspiration, ability, thought, imagination, dexterity, skill, or expertise expressed in tangible form. Buton weaving is the intellectual property produced by the native people of Buton or traditional communities. So that the typical buton weaving can be said to be a copyright that is mandatory or must be protected, especially in the art of motifs.Based on the explanation above, the writer needs to review the "Copyright Protection of Buton Weaving Motifs". As for the problem is how is copyright protection for the typical Buton weaving motif according to Law Number 28 of 2014 concerning Copyright?

\section{Method Of Research:-}

This research uses normative legal research methods. Normative legal research is research conducted by examining library materials ${ }^{3}$. This research is using the statute approachand conceptual approach. Statute approach is done by examining all laws and regulations that relevant to the legal issues are being addressed while the Conceptual Approach depart from the views and doctrines that developed in the jurisprudence. By studying the views and doctrines in the science of law, researchers will find ideas that making us to have to legal understandings, legal concepts, and legal principles that relevant to the issue at hand. Understanding of these views and doctrines is the backrest for researchers in building a legal argument to solving the issues at hand ${ }^{4}$.In normative legal research library materials as basic data that in research science are classified as secondary data ${ }^{5}$. In legal research, secondary data includes: first, primary legal material is binding legal material, and consists of basic norms Constitution of the Republic of Indonesia 1945 and MPR Provisions, statutory regulations laws and Law Number 28 Year 2014 concerning Copyright. Second,secondary legal materials, which provide explanations regarding primary legal materials, such as research results, work from legal circles, and so on, and Third, Tertiary legal materials, namely legal materials that provide instructions or explanations for primary and secondary legal materials, like an Indonesian dictionary, or a legal dictionary. The technique of collecting legal materials used in this research is the study of documentation and field studies on relevant agencies, namely the Department of Industry and Trade of the City Baubau and weaving community in the City Baubau. After the data has been collected, it is then analyzed with a qualitative descriptive method, namely analyzing by describing symptoms or phenomena and facts obtained from the field objectively to answer the problems in this study.

\section{Discussion:-}

\section{Buton Weaving Motif}

Motif in this case can be interpreted as a form of basic of decoration which normally would be a pattern that is repeated in a craft or art. So, the motif can be interpreted as a basic element in art . Some of buton weaving fabrics have patterns / themes that contain certain meanings.

The theme of the buton weaving fabric motif itself is very diverse, ranging from flora, fauna, culinary, natural conditions and others. Variety of motifs ornamental that exist on a piece of cloth woven Buton not only beautiful but also contains values of the teachings are taken from the philosophy of life that comes from tradition accompanied by the values of religion embraced by society Buton .

Fabrics woven Buton made by using the tool weaving traditional or ordinary referred by "Alat Tenun Bukan Mesin" (ATBM). ATBM is a means of weaving traditional but has little touch of technology that can speed up the process

\footnotetext{
${ }^{3}$ Soerjono Soekanto dan Sri Mamudji, Normative Legal Research: A Brief ReviewEd. 1. Cet. 16. Jakarta: Rajawali Pers, 2014, p. 13.

${ }^{4}$ Peter Mahmud Marzuki, Legal Research, Kencana Prenada Media Group, Jakarta, 2011, p. 24.

${ }^{5}$ Soerjono Soekanto dan Sri Mamudji,Op.Cit, p. 24.
} 
of weaving . In essentially handloom consists of a tool to spread the yarn. Besides that handloom is also the issue of the classical in the weaving of traditional such as length and width of the fabric that is limited can be resolved .

In general Button weaving consists of six motifs, such as:

1. Bhia Kolau is a checkered motif.

2. Bhia-Bhia Yitanu is a stripe motif.

3. Bhia Angka is the application of geometric ornaments or certain shapes such as stars.

4. Bhia Kasopa is a small stripe motif.

5. Bhia Boke is the weaving ikat motif because the yarn that has been tied with leather corn as much as 4 bunch, 8 bunch and 16 bunch, then dipped in dye in accordance with the wishes.

6. Bhia Botu is a motif in the form of yarn with small fibers.

\section{Copyright Protection of Buton Weaving Motifs}

The connection of the law regulations, that concerning about Buton weaving motif, the Copyright Law which regulate based on the classification of protected a creation in accordance with Article 38 and 40 of Law number 28 of 2014 concerning Copyright, is as follows:

\section{Article 38}

1. Rights of Copyright on the expression of cultures traditional held by the State.

2. The state is obliged to inventory, protected and maintain the expression of traditional culture as referred to in paragraph (1).

3. The use of traditional cultural expressions as referred to in paragraph (1) must pay attention to the values that live in the bearer the community.

4. The provision is further on Rights Reserved which iheld by the State on the expression of the culture of traditional as referred to in paragraph (1) governed by Rule Government.

Protection of buton weaving motifs as copyright works can be seen in the explanation of Article 38 paragraph (1) of the Copyright Act, wherein buton weaving motifs can be said to be works of art in a two-dimensional form made of textiles or a combination. So based on the explanation of the article, the weaving of Buton is a Traditional Cultural Expression.

In Article 39 of Law Number 28 Year 2014 concerning Copyright states that copyright in traditional cultural expressions is held by the State. The state is obliged to inventory, protect and maintain traditional cultural expressions. In Article 39 paragraph (4) of Law Number 28 Year 2014 states that further provisions concerning Copyright held by the State for traditional cultural expression are regulated by Government Regulations, but the copyright related to traditional cultural expressions held by the State there is not yet Government Regulation, so it is very vulnerable to be exploited by other parties, because it is a source of knowledge that can be commercialized.

As one of the protected works based on Article 58 of Law Number 28 Year 2014 concerning Copyright "applies for as long as of the life of the creator and continues for 70 (seventy) years after that the Creator dies since January 1 of the following year".

The one who have the Copyright is the common property (communal) of their owner's ethnic group, there is no individual who has a traditional cultural expression in person to person because the society do together to making the traditional cultural expression is alive. As communal property, traditional cultural expressions are considered free to be used and propagated by anyone, as long as their use and propagation do not violate the rules of the community that owns that traditional cultural expressions. However, although the traditional cultural expressions are considered as shared property of the community owners, the copyright for traditional cultural expressions is held by the state and contained in Article 39 of Law No. 28 of 2014 concerning Copyright. In Law Number 28 Year 2014 concerning Copyright, it does not state about the settlement of disputes over violations of traditional cultural expressions such as the buton weaving motif, in which the state holds the Copyright.

\section{Article 40}

Creation that is protected includes creation in the field of science knowledge, art, and literature, consisting on:

1. books, pamphlets, Typographical arrangement of the work of writing that was published, and all the results of the work of writing more;

2. public lecture/talk, lectures, speeches and other similar creations; 
3. teaching aids/proops made for the benefit of education and science;

4. songs and / or music with or without text;

5. drama, musical drama, dance, choreography, puppetry, and pantomime;

6. works of art in all forms such as paintings, drawings, engravings, calligraphy, art of sculpturing, sculpture, or collage;

7. Applied Art;

8. Architectural Works;

9. Map;

10. Batik artwork or Other batik motifs;

11. Photography works;

12. Portrait;

13. Cinematographic Works;

14. translations, interpretations, adaptations, anthologies/potpourri, databases, adaptations, arrangements, modifications and other works resulting from the transformation;

15. translation, adaptation, arrangement, transformation, or modification of traditional cultural expressions;

16. compilation of works or data, both in a format that can be read by a Computer Program or other media;

17. compilation of traditional cultural expressions as long as they are original works;

18. video game; and

19. Computer program.

20. Creation as referred to in paragraph (1) letter $n$ is protected as a separate creation without prejudice to the Copyright of the original creation.

21. Protection as referred to in paragraph (1) and paragraph (2), includes protection for a creation that no announced or has not yet been announced but has been realized in a tangible form that enables the Duplication of that creation.

Based on Article 40 paragraph (1) of the Copyright Act, forms of protected works are works in the fields of science, art and literature. In Article 40 paragraph (1) letter $\mathrm{j}$ states that batik artwork and other motifs are protected creations. Further explained in the explanation of Article 40 paragraph (1) letter $\mathrm{j}$ which is meant by other motifs of art work, namely motifs which are the wealth of the Indonesian people found in various regions such as the art of buton weaving and other motifs that are contemporary, innovative and continue to be developed. When seen from the provisions in the Copyright Act, the buton weaving motif is one of the creations protected by the Copyright Act. In the Copyright Act, it is regulated to protect Indonesia's traditional culture from commercial use by foreign parties without the government's permission as a Copyright holder. Buton has several weaving craftsmen, which are marked by the existence of weaving villages such as Topa / Sulaa weaving villages, Bone-Bone weaving villages, Sambali weaving villages and liwuto weaving villages which have created various motifs. Without realizing the various buton woven motifs that are created will be very easily imitated by others, and will certainly harm the creator or owner of these motifs.

Based on field research results, buton woven motifs created have not yet been recorded and registered as copyrighted works, this happens because they do not yet know the mechanism of copyright registration, the procedure for recording a copyrighted work is still considered complicated and requires large costs for some creators of weaving motifs buton, while buton woven motifs were created quite a lot, so the creators of buton woven motifs chose to focus more on the way of marketing their products rather than recording their works, buton weaving craftsmen also did not know the types of violations against a creation and buton weaving craftsmen lacked understanding of rights economic and moral rights that they get over the resulting work, which they know are just motifs that they create get protection, do not know that the motif must be recorded in order to obtain legal certainty. Even though the procedure for recording the motif of the work is already relatively easy and in the process will be accompanied by the Department of Industry and Trade, in addition to the cost for recording a work has been subsidized by the government based on Government Regulation of the Republic of Indonesia Number 45 of 2016 concerning Types and Rates of Types of Revenue Non-Tax State, thus it can be said the implementation of legal provisions on buton woven motifs based on Law Number 28 of 2014 concerning Copyright has not been implemented effectively. 


\section{Factors of Weak Copyright Protection for Buton Weaving Motifs}

Law as protection of human interests. For human interests to be protected, laws must be implemented. By because it is, it is not surprising when P. Scholten says that " when the law not been implemented, then it is no longer referred to as the law". Implementation of the law can be occur in a normal, peaceful, but also can occur because of a violation of law. In terms of this law are violated it must be enforced. Through the law enforcement, this law becomes a reality. ${ }^{7}$ According Sudikno Mertokusumo stated that the enforcement of the law is the execution of the law or implementation of the laws it self. ${ }^{8}$ The implementation of the law will be related to two components, namely: The existence of a set of regulations that function to regulate human behavior in resolving disputes that arise among community members and there is a set of people or institutions that carry out tasks in order to rule that made it respected and not violated. ${ }^{9}$ Law as one of the aspects of the life of human beings grow and evolve along with the development of society. The rate of development of the society which is supported by the science of science and technology of modern will always demand the holding of efforts to reform the law, so that the provisions of the law that applies is always able to meet the needs of society and in terms of the rule of law is always consistent and consequent. ${ }^{10}$ The law was alone in his form as the regulations clearly not be able to do all of it . By this be relevant for the discussion about the factors that affect the rule of law.

That Factors according to Soerjono Soekanto are as follows : factor rule of law / regulation that itself , factors officer / enforcement of law , factors means or facilities, the factors of society and factors of culture. ${ }^{11}$ This opinion is in line with what was stated by Lawrence Friedman who stated that law enforcement is influenced by three things, namely the substance of the law ( legal subtance ), Legal structure ( legal structure ), legal culture ( legal culture ). The factors are mutually related, because it is the essence of the rule of law as well as the starting measure of the effectiveness of the rule of law. As for the factors of weak protection of the rights of copyright on weaving motifs Buton are as follows:

\section{a. Legal Subtance}

Protection of copyright on a typical weaving motifs Buton regulated in Law No. 28 of 2014 concerning Copyright. In the elucidation of Article 38 paragraph (1) of the Copyright Law, where the buton woven motif can be said to be a work of art in a two-dimensional form made from textiles or a combination thereof. Then, Article 40 paragraph (1) letter $\mathrm{j}$ states that batik artwork and other motifs are protected creations. Further explained in the explanation of Article 40 paragraph (1) letter $j$ where what is meant by other motif art works are motifs which are the wealth of the Indonesian people found in various regions such as the art of buton weaving and other motifs which are contemporary, innovative and continue to be developed. When seen from the provisions in the Copyright Act, the buton weaving motif is one of the creations protected by the Copyright Act.

Protection of buton weaving motifs based on Law Number 28 Year 2014 Regarding Copyright has not been implemented effectively. This is because the buton weaving motifs created have not yet been recorded and registered as copyrighted works, it happens because they do not know the mechanism of copyright registration, buton weaving motifs creators choose to focus more on the way of marketing their products rather than recording their works, weaving craftsmen Buton also does not know the types of violations of a work and buton weavers lack understanding about the economic rights and moral rights they obtain from the work they produce.

\section{b. Legal Structure}

Legal structure associated with law enforcement. Every law enforcement sociologically has a status and role. Place is a certain position in the social structure. The position is a forum which contains certain rights and obligations. Rights and obligations themselves are roles. Therefore, a person who has a certain position is usually sociologically called stakeholders (role occupant).

Factors of legal structures in relation to the protection of copyright on weaving motifs Buton is that local governments do not already have an understanding of the technical preparation of the application for registration of

\footnotetext{
${ }^{6}$ Satjipto Rahardjo, Law and Society, Angkasa, Bandung, 1986, p. 69.

${ }^{7}$ SudiknoMertokusumo, Knowing the Law , An Introduction, Liberty, Yogyakarta, 1991, p. 160

${ }^{8}$ Ibid, p. 81

${ }^{9}$ ibid

${ }^{10}$ ibid

${ }^{11}$ Soerjono Soekanto, actors That Mempe at influencing Law Enforcement, Rajawali Pers, Jakarta, 2008, p. 9.
} 
the copyright in weaving motifs of Buton. This is due to the lack of human resources who have competence in the field of intellectual property rights, especially copyright. The limited of human resources who have competence in the field of intellectual property rights especially copyright becomes a serious problem, bearing in mind the technical preparation of a copyright request requires carefulness, if this is left out, it will result in the process of copyright registration for buton woven motifs taking a long time because in the application there are errors or deficiencies, so that the application is returned and repaired. In addition, the lack of socialization or counseling regarding the mechanism of registration of intellectual property rights, especially copyrights by local governments. Whereas local governments can collaborate with the Ministry of Law and Human Rights of Southeast Sulawesi representatives to conduct socialization activities or training in copyright registration.

\section{c. Legal Culture}

Enforcement of the laws is relating closely to factor of the workings of the law. Rules of law is a set of norms that shows what that had to do or anything that should happen. The Working of the law is an institution in the community, then it needs to incorporate a factor that becomes an intermediary that allows the law that do regenerate or allow the application of the norms of the law was. The application of law can only occur through humans as intermediaries. The entry of humans into talks about the law, especially in the relationship with the workings of the law that, will bring the vision of the law as the work of man in the society, so that the factors which give the load effect (impact) to the law not to be restricted. ${ }^{12}$

Protection of the rights of copyright on the motif of weaving typical of Buton needed the consciousness of society. In Basically rights reserved enough to be announced just 've got the protection of the law, but to obtain the certainty of the law also need to be registered. In the registration process itself there are files that must be met. However, what happens is people still less understand the mechanism of registration of rights of copyright right that must be met. In addition to that, the cost of which is relatively expensive to acquire the rights of copyright into the cause of the people reluctant to perform the registration rights reserved, It is confirm that the availability of the source of the power of man who understands the technical preparation of the application for registration of the right to the wealth of intellectual, especially the rights of copyright becomes a thing that is important. In addition, the culture of the Buton community is very thick because it is an area of the Sultanate of Buton which has a lot of regional art culture. With many arts area one of them weaving Buton, people tend to be pleased if their products imitated by the other, because the case is to bring a joy of its own for the creator. Of course the culture sort of this is very hamper the enforcement of the protection of the rights of copyright in the era of liberalization when this. It is of course only be a challenge itself to the government area, because changing the paradigm as it is not as easy as reversing the palm of the hand.

\section{Conclusion and Recommendation:-}

Based on the above discussion it can be concluded as follows:

1. Buton woven consists of six motifs, among others motif bhia kolau (motif boxes), motif bhia-bhia yitanu (motif stripes), motif bhia angka (ornaments geometric like a star), motif bhia kasopa ( motif stripes small ), motif bhia boke (motif woven cloth) and motif bhia Botu (motif yarn with fibers of small).

2. Copyright protection on Buton woven motifs is regulated in Law No. 28 of 2014 concerning Copyright in Article 38 paragraph (1), where the motif weaving Buton can be said as a work of art such in the form of two dimensions that are made from textiles or combinations thereof, and Article 40 paragraph (1) letter $\mathrm{j}$ stated that the work of art of batik and art motifs other is a creation that is protected. More advanced in the elucidation of Article 40 paragraph (1) letter (j) are referred to the work of art motifs more that motif is the wealth of the nation of Indonesia are in various areas such as art weaving Buton and art of other motifs that are contemporary, innovative and continuously developed.

3. Factors of Weak Copyright Protection for Buton Weaving Motif: a) Factors legal subtance: Provisions of Law No. 28 of 2014 concerning Copyright has not been implemented effectively because the motifs of Buton weaving have not recorded and registered as copyrighted works because they do not know the mechanism of copyright registration, do not know the types of violations against the creation and craftsmen of Buton weaving, lack understanding of related economic rights and the moral that they get for the creation they produce, b) Factors legal structure: the lack of resources the power of man which has competency in the field of rights of the wealth of intellectual, especially the rights of copyright and the lack of socialization or counseling regarding the mechanism of the registration rights of the wealth of intellectual, especially rights reserved, and c) Factors

${ }^{12}$ Rahardjo, Law and Society, Op.Cit., p. 48 
legal culture: the community or weaving craftsmen still do not understand the mechanism of registration of copyright rights that must be fulfilled. In addition to that, the cost of which is relatively expensive to acquire the rights of copyright into the cause of the people reluctant to do the registry of copyright.

The suggestions that will be conveyed are as follows:

1. Government Areas need to do the socialization and training in the field of rights of the wealth of intellectuals, especially the rights of copyright so that the public can understand the protection of the law on the results of his work, especially the typical weaving motifs of Buton.

2. Society, especially the craftsman of weaving typical of Buton in order to increase the awareness of the law will be important to the protection of the rights of copyright on the motif of weaving typical of Buton and against woven motifs Buton that made to be registered immediately to obtain legal certainty.

\section{References:-}

1. Director General of IPR and EC- ASEAN Cooperation on Intellectual Property Rights (ECAP II), 2006.

2. I Gede Pitana, Introduction to Tourism Science, ANDI, Yogyakarta, 2009.

3. Imran Kudus et al, Variety of Buton Sarong Ornaments, Bappeda Kota Baubau, 2016.

4. Peter Mahmud Marzuki, Legal Research, Kencana Prenada Media Group, Jakarta, 2011.

5. Satjipto Rahardjo, Law and Society, Angkasa, Bandung, 1986.

6. Soerjono Soekanto, Factors That Influence Law Enforcement, Rajawali Pers, Jakarta, 2008.

7. Soerjono Soekanto \& Sri Mamudji, Normative Legal Research (A Brief Review), Rajawali Pers, Jakarta, 2001.

8. SudiknoMertokusumo, Knowing the Law, An Introduction, Liberty, Yogyakarta, 1991. 